\title{
Determination of Chemical, Nutritional and Fermentation Properties of Citrus Pulp Silages
}

\author{
Selma Buyukkilic Beyzi", İsmail Ülger, Mahmut Kaliber, Yusuf Konca
}

Department of Animal Science, Erciyes University, 38039 Kayseri, Turkey

\section{A R T I C L E I N F O}

\section{Research Articles}

Received 24 September 2018 Accepted 11 December 2018

Keywords:

Orange

Tangerine

Lemon

Silage

Fermentation

\section{A B S T R A C T}

This study was carried out to investigate the possibilities of making silage from fruit juice industry waste.For this purpose, orange, lemon and tangerine pulp silage quality have been determined by comparing silage with maize and beet pulp silage.Treatment groups; 1) orange, 2) tangerine, 3) lemon, 4) maize and 5) sugar beet pulp. The silages were evaluated after 2 months from ensiling in the following areas: subjective evaluation, $\mathrm{pH}$, dry matter, organic matter, crude protein, acid detergent fiber, neutral detergent fiber, ether extract and energy values (metabolizable energy) and net energy for lactation were calculated. As a result, it was determined that fruit juice industry residues were lower in terms of dry matter, but they contained higher energy due to their high organic matter content, digestibility and low cellulose content. In addition, it was determined that citrus pulp was evaluated as silage without any contribution.

\section{Narenciye Grubu Meyve Posası Silajlarının Kimyasal, Besinsel ve Fermantasyon Özelliklerinin Belirlenmesi}

M A K A LE B İL Gİ İ ÖZ

\section{Araștırma Makalesi}

Geliş 24 Eylül 2018

Kabul 11 Aralık 2018

Anahtar Kelimeler:

Portakal

Mandalina

Limon

Silaj

Fermantasyon

\section{Ö Z}

Bu çalışma meyve suyu sanayi artıklarından silaj yapılabilme imkanlarını araştırmak amacıyla yapılmıştır. Bu amaçla meyve suyu fabrikasından temin edilen portakal, limon ve mandalina posaları; silaj yapımı yaygınlaşan mısır ve pancar posası silaj1 ile karşılaştırılarak silaj kaliteleri belirlenmiştir. Muamele grupları; her biri üçer tekerrür olmak üzere 1) portakal, 2) mandalina, 3) limon 4) mısır hasılı ve 5) pancar posasıdır. İki ay silolama sonrası açılan silajlarda: subjektif değerlendirme, $\mathrm{pH}$, kuru madde, organik madde, ham protein, ADF, NDF, ham yağ, gaz üretimleri, organik madde sindirilebilirlikleri ve enerji değerleri hesaplanmıştır. Araştırma sonuçları incelendiğinde, meyve suyu sanayi artıklarının kuru madde bakımından daha düşük olduğu ancak organik madde, sindirilebilirlik ve selüloz içeriklerinin düşük olmasına bağlı olarak daha yüksek enerji içerdiği tespit edilmiştir. Ayrıca narenciye posalarının herhangi bir katkı katılmaksızın silolanarak değerlendirilmesinin mümkün olduğu tespit edilmiştir.

\footnotetext{
"Sorumlu Yazar:

E-mail: sbuyukkilic@erciyes.edu.tr
} 


\section{Introduction}

Silage feeds are an important alternative to meet the roughage needs of ruminant animals. Silage can be done successfully from many plant materials, which fruit pulps are one of these. In Turkey, maize is generally used as a silage feed crop, and other crops suitable for silage such as wheat, meadow grass, food industry by-products (pulps etc.), which are alternative forage feed sources that cannot be utilized sufficiently (Özen et al., 2005). In the previous studies, alternative feed sources have been determined to increase the profitability by lowering the feed input costs. For this reason, fruit juices, a by-product obtained after fruit juice production, are an important alternative source of forage feed that can be used in ruminant nutrition (Filya et al., 2006, Duru and Kaya, 2015). Studies on the use of fruit pulp silages in animal nutrition (Ashbell, 1994; Yalçınkaya et al., 2012; Canbolat et al., 2014) showed large differences in the quantities of these materials. Generally, food factory residues such as apples, oranges, lemons, tomatoes and grape pulps are used for silage production (Yalçınkaya et al., 2012). Some of these fruits are rich in antioxidants, carotenoids, anthocyanins, pectins, fatty acids, flavonoids and phenolic acids and some vitamins and minerals (Velioglu et al., 1998) may also be important contributors to silage quality (Ülger et al., 2015).

Citrus fruits are a group of plants which include such as orange, tangerine, grapefruit and lemon tree. Total world citrus production is average 69.4 million tonnes/year and about $3 \%$ of the total production of citrus fruits (orange (Citrus sinensis), tangerine (Citrus reticulata) and lemon (Citrus lemon)) is provided by Turkey. Low quality or non-consumable fruits and its waste products cause both environmental pollution and serious economic losses. The waste products can easily spoil due to the high-water content during their storage. For this reason, an amount of waste productsis evaluated by feeding of the animals as freshly in the nearby fruit juice factories, but an important part of these products may not evaluated. It is possible that the citrus pulps can be preserved for a longer time by making silages and it will be possible to use this as an alternative feed for ruminant animals. Thus, it is possible to reduce environmental pollution caused by waste products. The purpose of this study was to investigate the possibility of silage of orange, tangerine and lemon pulps, as well as the determination of feed value in ruminant animals.

\section{Materials and Methods}

In the study; orange, tangerine and lemon pulps were obtained from a private fruit juice factory operating in Kayseri. Maize was obtained from Erciyes University Agricultural Research and Application Center (ERUTAM) and beet pulp was obtained from Kayseri Sugar Factory. Silo materials were exposed to fermentation for 60 days by pressing in glass jars with a volume of $5 \mathrm{~L}$. In silages, at the end of two months $(60$ days), $25 \mathrm{~g}$ of the silage sample was mixed and homogenized in $100 \mathrm{ml}$ of distilled water for 5 minutes and then $\mathrm{pH}$ measurements were made (Polan et al., 1998). Analyzes of dry matter (DM), crude protein (CP) and organic matter (OM) of silages according to the methods described in AOAC (1990), neutral detergent fiber (NDF) and acid detergent fiber (ADF) analyzes were determined according to Van Soest and Robertson 1979) and Goering and Van Soest (1975) respectively. Water soluble carbohydrate (WSC) contents were determined by phenol sulfuricacid method reported by Dubois et al. (1956). Acetic, propionic and butyric acid analyzes in silage samples were carried out by gas chromatography (Schimadzu GC 2010 Plus, with a capillary column; Stabilwax-DA, $30 \mathrm{~m}, 0.25 \mathrm{~mm}$ ID, 0.25) and lactic acid analysis according to Barker and Summerson (1941). The invitro gas production technique reported by Menke and Steingass (1998) was used to determine organic matter digestibility (OMD) and metabolisableenergy (ME) and net energy lactation (NEL) levels of silages in vitro. Approximately $200 \pm 10 \mathrm{mg}$ of dried silage samples were placed in a special glass tubes (Model Fortuna, HäberleLabortechnik, Lonsee-Ettlenschieb, Germany) with a volume of $100 \mathrm{ml}$ for the detection of in vitro gas production quantities of silages and $\mathrm{ME}$ and organic matter digestibility (OMD) by Menke et al., (1979)were determined. The ME, NEL and OMD of silages are calculated according to the formulas below (Menke and Steingass, 1998):

$$
\begin{array}{ll}
\mathrm{OMD} & =14.88+0.889 \times \mathrm{GP}+0.45 \times \mathrm{CP}+0.651 \times \mathrm{Ash} \\
\mathrm{ME} & =2.20+0.1357 \times \mathrm{GP}+0.057 \times \mathrm{CP}+0.002859 \mathrm{EE} \\
\mathrm{NEL} & =0.101 \mathrm{GP}+0.051 \mathrm{CP}+0.112 \mathrm{EE} \\
\mathrm{OMD} & : \text { Organicmatter digestibility }(\%) \\
\mathrm{ME} & : \text { Metabolizable energy }(\mathrm{MJ} / \mathrm{kg} \mathrm{DM}) \\
\mathrm{NEL} & : \text { Net energy for lactation }(\mathrm{MJ} / \mathrm{kg} \mathrm{DM}) \\
\mathrm{GP} & : 24 \text {-hour net gas production } \\
\mathrm{CP} & : \% \text { Crude protein } \\
\mathrm{EE} & : \% \text { Ether extract }
\end{array}
$$

In the statistical analysis of the data obtained from the study, one-way ANOVA was used by SPSS (1997) package program and Duncan multiple comparison test was used in determining the differences between the groups.

\section{Results and Discussion}

The silage of citrus pulp materials dry mater (DM), crude protein $(\mathrm{CP})$, organic matter $(\mathrm{OM})$, ether extract (EE), crude cellulose (CC), acid detergent fiber (ADF), neutral detergent fiber (NDF) values are given in Table 1.

The DM levels of the raw silage materials used in the study were determined as the highest in maize and lemon pulp silages. CP level in the raw materials was detected at the highest beet and lemon pulps. The EE, ADF and NDF values were obtained highest in maize silage. The nutrient contents of citrus fruit silages obtained at the end of the study are given in Table 2. 
Table 1 Chemical content of raw silage materials

\begin{tabular}{l|ccccccc}
\hline \multirow{2}{*}{ Raw materials } & \multicolumn{7}{c}{ Parameters, DM \% } \\
\cline { 2 - 7 } & DM, \% & CP & OM & EE & CC & ADF & NDF \\
\hline Orange pulp & 20.13 & 4.63 & 96.45 & 0.81 & 6.83 & 14.44 & 15.51 \\
Tangerine pulp & 21.45 & 4.81 & 96.16 & 0.98 & 7.53 & 13.15 & 14.84 \\
Lemon pulp & 23.79 & 7.56 & 95.28 & 2.84 & 11.52 & 19.45 & 21.61 \\
Maize & 26.32 & 6.26 & 80.98 & 1.84 & 26.15 & 37.63 & 59.05 \\
Sugar beet pulp & 20.08 & 8.65 & 93.25 & 0.38 & 19.32 & 26.75 & 36.73 \\
\hline
\end{tabular}

DM: dry matter; CP: crude protein; OM: organic matter; EE: ether extract; CC: crude cellulose; ADF: acid detergent fiber; NDF: neutral detergent fiber

Table 2 Chemical composition of citrus, maize and sugar beet pulp silages

\begin{tabular}{l|cccccccc}
\hline \multirow{2}{*}{\multicolumn{1}{c|}{ Silages }} & \multicolumn{9}{c}{ Parameters, DM \% } \\
\cline { 2 - 9 } & $\mathrm{pH}$ & $\mathrm{DM}, \%$ & $\mathrm{CP}$ & OM & EE & CC & ADF & NDF \\
\hline Orange pulp & $3.61^{\mathrm{c}}$ & $15.87^{\mathrm{c}}$ & $9.20^{\mathrm{b}}$ & $94,78^{\mathrm{d}}$ & $1.87^{\mathrm{b}}$ & $11.91^{\mathrm{c}}$ & $22.59^{\mathrm{c}}$ & $21.55^{\mathrm{c}}$ \\
Tangerine pulp & $3.73^{\mathrm{b}}$ & $16.23^{\mathrm{c}}$ & $10.79^{\mathrm{a}}$ & $94.02^{\mathrm{c}}$ & $2.50^{\mathrm{a}}$ & $11.43^{\mathrm{c}}$ & $26.88^{\mathrm{b}}$ & $21.55^{\mathrm{c}}$ \\
Lemon pulp & $3.63^{\mathrm{c}}$ & $21.22^{\mathrm{b}}$ & $7.91^{\mathrm{c}}$ & $94.33^{\mathrm{c}}$ & $1.82^{\mathrm{b}}$ & $10.69^{\mathrm{c}}$ & $22.36^{\mathrm{c}}$ & $23.35^{\mathrm{c}}$ \\
Maize & $3.84^{\mathrm{a}}$ & $36.97^{\mathrm{a}}$ & $6.57^{\mathrm{d}}$ & $90.16^{\mathrm{a}}$ & $2.41^{\mathrm{a}}$ & $23.37^{\mathrm{a}}$ & $38.57^{\mathrm{a}}$ & $58.37^{\mathrm{a}}$ \\
Sugar beet pulp & $3.50^{\mathrm{d}}$ & $21.94^{\mathrm{b}}$ & $9.59^{\mathrm{b}}$ & $93.33^{\mathrm{b}}$ & $0.88^{\mathrm{c}}$ & $17.39^{\mathrm{b}}$ & $27.65^{\mathrm{b}}$ & $34.60^{\mathrm{b}}$ \\
SEM & 0.032 & 2.207 & 0.227 & 2.550 & 0.131 & 1.025 & 1.128 & 2.635 \\
P & $<0.001$ & $<0.001$ & $<0.001$ & $<0.001$ & $<0.001$ & $<0.001$ & $<0.001$ & $<0.001$ \\
\hline
\end{tabular}

a-d: The differences between the means indicated by different letters in the same column are statistically significant; SEM: standard error of means; P: probability; DM: dry matter; CP: crude protein; OM: organic matter; EE: ether extract; CC: crude cellulose; ADF: acid detergent fiber; NDF: neutral detergent fiber.

Table 3 Gas production parameters and nutritional composition of citrus, maize and sugar beet pulp silages

\begin{tabular}{l|cccccc}
\hline \multirow{2}{*}{\multicolumn{1}{c|}{ Silages }} & \multicolumn{5}{c}{ Parameters } \\
\cline { 2 - 7 } & $\mathrm{GP}, \mathrm{mL}$ & $\mathrm{CH}_{4}, \mathrm{~mL}$ & $\mathrm{CH}_{4}, \%$ & $\mathrm{ME}, \mathrm{Mj} / \mathrm{kg}$ & $\mathrm{NEL}, \mathrm{Mj} / \mathrm{kg}$ & $\mathrm{OMD}, \mathrm{DM} \%$ \\
\hline Orange pulp & $77.00^{\mathrm{a}}$ & 11.73 & 15.24 & $12.72^{\mathrm{a}}$ & $8.53^{\mathrm{a}}$ & $87.76^{\mathrm{a}}$ \\
Tangerine pulp & $74.67^{\mathrm{ab}}$ & 11.77 & 15.77 & $12.42^{\mathrm{ab}}$ & $8.28^{\mathrm{b}}$ & $86.50^{\mathrm{a}}$ \\
Lemon pulp & $74.00^{\mathrm{ab}}$ & 12.39 & 16.78 & $12.31^{\mathrm{ab}}$ & $8.18^{\mathrm{bc}}$ & $84.61^{\mathrm{ab}}$ \\
Maize & $63.20^{\mathrm{c}}$ & 10.43 & 16.51 & $10.83^{\mathrm{c}}$ & $6.92^{\mathrm{c}}$ & $74.67^{\mathrm{c}}$ \\
Sugar beet pulp & $64.90^{\mathrm{bc}}$ & 10.63 & 16.37 & $11.08^{\mathrm{bc}}$ & $7.13^{\mathrm{bc}}$ & $77.33^{\mathrm{bc}}$ \\
SEM & 1.802 & 0.264 & 0.200 & 0.246 & 0.209 & 1.658 \\
P & 0.014 & 0.099 & 0.161 & 0.013 & 0.012 & 0.010 \\
\hline
\end{tabular}

a-d: The differences between the means indicated by different letters in the same column are statistically significant; SEM: standard error of means; P probability; GP: Gas production; $\mathrm{CH}_{4}$ : methane production; ME: metabolizable energy; NEL: net energy lactation; OMD: Organic matter digestibility

One of the important criteria for determining the qualities of silages is the $\mathrm{pH}$ value (Kiermeier and Renner, 1963). In this study, $\mathrm{pH}$ values of silages (3.503.84) were found similar to optimum silage $\mathrm{pH}$ values of 3.8-4.2 (Coskun et al., 1998). The $\mathrm{pH}$ value of the beet pulp was significantly lower than the other groups ( $P$ $<0.001$ ). When the study findings (Table 2) were examined, it was found that the DM levels of the silages were changed between $15.87 \%$ in the orange group and $36.97 \%$ in the maize silage group. These values were lower than the average DM values (25-35\%) reported for silages (Demirel and Yıldı, 2000). Ergül et al. (2001) reported that the $\mathrm{pH}$ values of the silages prepared by adding broiler bottoms at $0,15,30$ and $45 \%$ to fruit juice pulps and wet sugar beet pulp were between 4.1-4.2, Deniz et al. (2001) found similarities in this study between groups of 3.72-4.30 in groups containing $20 \%$ DM. Avc1 et al. (2005) found that $\mathrm{pH}$ was 3.64-4.33 in silage containing $17 \% \mathrm{DM}$ and $\mathrm{pH} 3.96-4.34$ in silage containing $20 \%$ DM. In a study, the $\mathrm{pH}$ value of beet pulp was found to be 3.76 but in this study the $\mathrm{pH}$ value of sugar beet pulp silage was found to be lower (Ülger et al., 2015).

The silages' $\mathrm{OM}, \mathrm{CP}, \mathrm{EE}, \mathrm{CC}, \mathrm{ADF}$ and $\mathrm{NDF}$ contents were found to be significant between groups ( $P$ $<0.001$ ) (Table 1). There are few studies on the evaluation of citrus pulps as silage feed. The studies have done generally a mixture of citrus fruits. In some studies, about orange pulp, the ratios of $\mathrm{OM}, \mathrm{CP}, \mathrm{EE}$ and $\mathrm{ADF}$ were $96.5 \%, 6.4 \%, 4 \%$ and $15 \%$ respectively (MartinezPascual and Fernandez-Carmona (1980), Lanza (1984), Cerveraetal., (1985), Megiasetal., (1993), Silva et al. (1994), Fegeros et al. (1995) and Miron et al. (2001)). In a study on lemon varieties, the differences between the varieties were found to be significant; the mean values of $\mathrm{OM}, \mathrm{CP}, \mathrm{EE}, \mathrm{NDF}$ and ADF were $94.73 \%, 7.4 \%, 5.60 \%$, $20.05 \%$ and $17.16 \%$, respectively (Özkan et al., 2017). In the present study, the citrus pulps group organic matter level was higher than maize silage, also contains lower cellulose and similar protein ratio. But in citrus group silages were included lower dry matter ratio than maize silage.

In the study, the GP values of silage materials were changed between $63.20 \mathrm{ml}$ (maize) - $77 \mathrm{ml}$ (orange) and the differences in GP values between silages were statistically significant $(\mathrm{P}<0.05)$. The 24 -hour methane production levels of groups ranged from $10.43 \mathrm{ml}$ to $12.39 \mathrm{ml}$ and from 15.24 to $16.78 \%$.The lowest and highest values for ME contents were determined as 10.83 MJ / kg DM (lemon) and 12.72 MJ / kg DM (orange), respectively $(\mathrm{P}<0.05)$. The highest $\mathrm{NEL}$ was $8.53 \mathrm{Mj} / \mathrm{kg}$ $\mathrm{DM}$ obtained from the orange group, this value was found 
to be at least $6.92 \mathrm{Mj} / \mathrm{kg} \mathrm{DM}$ in the maize group $(\mathrm{P}<0.05)$. The OMD values varied between $74.67 \%$ (maize) and $87.76 \%$ (orange). In a study of different types of lemon pulp silages, total gas production was reported between 68.7 and $77.6 \mathrm{~mL}$. In the same study, $\mathrm{CH} 4$ production ranged from 10.1 to $13.6 \mathrm{~mL}$, ME value ranged from 12.0 to $13.2 \mathrm{Mj} / \mathrm{kg}$, and $\mathrm{OMD}$ ranged from 82.7 to $91.5 \%$ (Özkan et al., 2017).

In the study, WSC values of silages were found statistically significant $(\mathrm{P}=0.05)$. The lowest value was found in the orange group at $3.45 \mathrm{~g} / \mathrm{kg}$, the highest value was detected in the $7.27 \mathrm{~g} / \mathrm{kg}$ beet pulp group. Differences between the groups were statistically significant for LA concentration $(\mathrm{P}=0.004)$. When the highest LA value was determined in a group of $126.06 \mathrm{~g} / \mathrm{kg}$ sugar beet pulp, the lowest value was found in the tangerine group 31.13 $\mathrm{g} / \mathrm{kg}$. In the previous studies, the mean values of LA, AA, $\mathrm{PA}$ and BA in orange silage reported as $21.9 \mathrm{~g} / \mathrm{kg}, 29.8$ $\mathrm{g} / \mathrm{kg}, 2.9 \mathrm{~g} / \mathrm{kg}$ and $0.5 \mathrm{~g} / \mathrm{kg}$, respectively (MartinezPascual and Fernandez-Carmona (1980), Lanza (1984), Cerveraetal (1985), Megiasetal (1993), Silva et al. (1997), Scerra et al. (1994), Fegeros et al. (1995) and Miron et al. (2001)). In the current study, lactic acid production is higher than in previous studies, which may be due to the fact that the proportion of material remaining in the pulp during the production of fruit pulps does not vary with the sugar content. In addition, a good fermentation was observed in fruit pulp group silages while in the maturation period in this study.

Table 4 Fermentation parameters of citrus, maize and sugar beet pulp silages

\begin{tabular}{l|ccccc}
\hline \multirow{2}{*}{\multicolumn{1}{c|}{ Silages }} & \multicolumn{4}{c}{ Parameters, g/kg DM } \\
\cline { 2 - 6 } & WSC & LA & AA & PA & BA \\
\hline Orange pulp & $3.45^{\mathrm{c}}$ & $72.61^{\mathrm{bc}}$ & 28.8 & 1,24 & 0.20 \\
Tangerine pulp & $4.00^{\mathrm{bc}}$ & $31.13^{\mathrm{d}}$ & 14.15 & 0,88 & 0.01 \\
Lemon pulp & $5.65^{\mathrm{ab}}$ & $37.51^{\mathrm{cd}}$ & 17.02 & 1,02 & 0.02 \\
Maize & $4.46^{\mathrm{abc}}$ & $101.21^{\mathrm{ab}}$ & 31.60 & 2,08 & 0.24 \\
Sugar beet pulp & $7.27^{\mathrm{a}}$ & $126.06^{\mathrm{a}}$ & 35.06 & 2,15 & 0.26 \\
SEM & 0.52 & 12.32 & 8.21 & 0.05 & 0.01 \\
P & 0.050 & 0.004 & 0.042 & 0.051 & 0.054 \\
\hline
\end{tabular}

a-d: The differences between the means indicated by different letters in the same column are statistically significant; SEM: standard error of means; P: probability; WSC; water soluble carbohydrates; LA: lactic acid; AA: acetic acid; PA: propionic acid

\section{Conclusion}

As a result, citrus pulps which are a waste material can be evaluated as silage. In this study, it was determined that citrus pulps can be ensiled alone and used as ruminant feed. Thus, the environmental pollution can be reduced with ensiling. So that economic livestock farming can be done by reducing both environmental gain and feed costs.

\section{Acknowledgment}

This study was supported by Scientific Research Projects Department of Erciyes University (with the project number: FBA-2016-6843).

\section{References}

AOAC. 1990. Association of Official Analytical Chemists. Official Methods of Analysis, 15th ed., Vol. 1. AOAC, Washington, DC, pp. 69-79.

Ashbell G. 1994. Basic Principals of preservation of forage, byproduct and residues as silage or hay. ARO. The Volcani Center Bet-Dagan, Israel

Avc1 M, Akdeniz H, Deniz S. 2005 Değişikkatkılarlahazırlananyaşşekerpancarıposasısilajlarının kalitesininbelirlenmesi. III. UlusalHayvanBeslemeKongresi, 7-10 Eylül, Adana.

Barker SB,Summerson WH.1941. The Colorimetric Determination of Lactic Acid in Biological Material. Journal of Biological Chemistry, 138: 535-554.

Canbolat Ö, Kamalak A, Kara H. 2014. The effects of urea supplementation on pomegranate pulp (Punicagranatum L.) silage fermentation, aerobic stability and in vitro gas production. Ankara Üniversitesi Veteriner Fakültesi Dergisi, 61: 217-223.
Cervera C, Fern'andez-Carmona J, Marti J. 1985. Effect of urea on the ensiling process of orange pulp. Animal of Feed Science Technology, 12: 233-238.

Coskun B, Seker E, İnal F. 1998. YemlerveTeknolojisi, SelçukÜniversitesiVeterinerFakültesiYayınÜnitesi, Konya.

Demirel M, Yıldız S. 2000. Hamur olum döneminde biçilen arpa hasılına kimi katkı maddeleri katılmasının silaj kalitesi ve rumende ham besin madelerinin y1kılımı üzerine etkisi. International Animal Nutrition Congress, 4-6 Eylül, Isparta, pp. 270-276.

Deniz S, Demirel M, Tuncer ŞD, Kaplan O, Aksu T. 2001. Değişik şekillerde üretilen şekerpancarı posası silajının süt ineği ve kuzu rasyonlarında kullanılma olanakları. 1. Kaliteli şeker pancarı posası silajının elde edilmesi. Turkish Journal of Veterinary Animal Science, 25: 1015-1020.

Dubois M, Giles KA, Hamilton JK, RebesPA, Smith F. 1956.Colorimetric method for determination of sugars and related substances. Analytical Chemistry, 28: 350-356.

Duru AA, Kaya Ş. 2015. Zeytin Posası Silajının Hayvan Beslemede Kullanım Olanakları. Mustafa Kemal Üniversitesi Ziraat Fakültesi Dergisi, 20(1).

Ergül M, Alçiçek A, Ayhan V, Kılıç A, Özkul H, Basmacioğlu H, Karaayvaz K. 2001. Kanatlı altlığının bazı yem kaynakları ile silolanma olanakları ve yem değeri. 1. Pancar posasının broiler altlığı ile silolanma olanakları ve yem değeri. Ege Üniversitesi Ziraat Fakültesi Dergisi, 38: 10188851.

Fegeros K, Zervas G, Stamouli S, Apostolaki E. 1995. Nutritive value of dried citrus pulp and its effect on milk yield and milk composition of lactating ewes. Journal of Dairy Science, 78: 1116-1121.

Filya İ, Hanoğlu H, Canbolat Ö, Sucu E. 2006. Kurutulmuş pirinanın yem değeri ve kuzu besisinde kullanılma olanakları üzerinde araştırmalar. 1. Yem Değerinin in situ Yöntemle Belirlenmesi. Uludağ Üniversitesi Ziraat Fakültesi Dergisi, 20: 1-12. 
Goering HK, Van Soest PJ. 1975. Forage Fiber Analysis (Apparatus, Reagents, Proceduresand Some Applications) Agricultural Hand-Book No:379, Washington, D.C., 11-19.

Kiermeier F, Renner E. 1963. Der pH wert aiskriterium der verwendbarkeit von silage für die milchviehFütterung. Das Wirtschaftseiq. Futterq, 106- 113.

Lanza A. 1984. Driedcitruspulp in animalfeeding. In:Holl'o,J.(Ed.), Proceedings of the International Symposium on FoodIndustriesandthe Environment. Budapest, Hungary. ElsevierPulishers, New York, NY, USA, pp. 189-198.

Mart'inez-Pascual J,Fern'andez-Carmona J. 1980. Composition of citrus pulp. Animal Feed Science Technology, 5: 1-10.

Meg'ias MD, Mart'inez-Teruel A, Gallego JA, N'ũnez JM. 1993. Chemical changes during the ensiling of orange peel. Animal Feed Science Technology, 43: 269-274.

Menke KH, Raab L, Salewski A, Steingass H, Fritz D, Schneider W. 1979. The estimation of the digestibility and metabolizable energy content of ruminant feedingstuffs from the gas production when they are incubated with rumen liquor in vitro. Journal of Agricultural Science, 93: 217-222.

Menke KH,Steingass H. 1988. Estimation of the energetic feed value obtained from chemical analysis and in vitro gas production using rumen fluid. Animal Research and Development, 28: 7-55.

Miron J, YosefE, Ben-Ghedalia D. 2001. Composition and in vitro digestibility of monosaccharide constituents of selected byproduct feeds. Journal of Agriculture and Food Chemistry, 49: 2322-2326.

Özen N, Kırkpınar F, Özdoğan M, Ertürk MM, Yurtman IYY. $2005 . \quad$ Hayvanbesleme. TMMOB, ZiraatMühendisleriOdasıTürkiyeZiraatMühendisliği VI. TeknikKongresi. Ankara, 3-7 Ocak 2005, s: 753-771.
ÖzkanÇÖ, Kaya E, Ülger İ, Güven İ, Kamalak A. Effect of Species on Nutritive Value and Methane Production of Citrus Pulps for Ruminants. HayvansalÜretim, 58: 8-12.

Polan CE, StieveDE, Garrett JL. 1998. Protein preservation and ruminal degradation of ensiled forage treated with heat, formic acid, ammonia, or microbial inoculant. Journal of Diary Science, 81: 765-776.

Silva AG, Wanderley RC, Pedroso AF, Ashbell G. 1997. Ruminal digestion kinetics of citrus peel. Animal Feed Science and Technology, 68: 247-257.

SPSS. 1997. SPSS User's Guide: Statistics, 9.05 ed. SPSS Inc.,

Ülger İ, Kaliber M, Beyzi SB, Konca Y. 2015. Yaş Şeker Pancarı Posasının Bazı Meyve Posaları ile Silolanmasının Silaj Kalite Özellikleri, Enerji Değerleri ve Organik Madde Sindirilebilirlikleri Üzerine Etkisi. Alınteri Zirai Bilimler Dergisi, 29: 19-25.

Van Soest PJ, Robertson JB.1979. Systems of Analyses for Evaluation of Fibrous Feed. In W.J. Pigden, C. C. Balch and M. Grahm (Eds). Proc. Int. Workshop on Standartization of Analytical Methodology for Feeds. Int. Dev. Res. Center, Ottowa.

Velioglu YS, Mazza G, Gao L, Oomah BD.1998. Antioxidant activity and total phenolics in selected fruits, vegetables, and grain products. Journal of Agricultural and Food Chemistry, 46: 4113-4117

Yalçınkaya MY, Baytok E, Yörük MA. 2012. Değişik Meyve Posası Silajlarının Bazı Fiziksel, ve Kimyasal Özellikleri. Erciyes Üniversitesi Veteriner Fakültesi Dergisi, 9: 95-106. 